\title{
SPINK1 wt Allele
}

National Cancer Institute

\section{Source}

National Cancer Institute. SPINK1 wt Allele. NCI Thesaurus. Code C51412.

Human SPINK1 wild-type allele is located within $5 q 32$ and is approximately $7 \mathrm{~kb}$ in length. This allele, which encodes pancreatic secretory trypsin inhibitor protein, is involved in the inhibition of premature trypsin-catalyzed zymogen activation in the pancreas. Certain allelic variants of the SPINK1 gene cause chronic pancreatitis and confer susceptibility to fibrocalculous pancreatic diabetes. Mutated forms of the pancreatic secretory trypsin inhibitor protein are also involved in the development of tropical calcific pancreatitis. 